\title{
Expressional Modulation of Connexin Isoforms in the Initial Segment of Male Rat treated with Estradiol Benzoate or Flutamide
}

\author{
${ }^{\dagger}$ Ki-Ho Lee \\ Dept. of Biochemistry and Molecular Biology, College of Medicine, Eulji University, Daejeon 301-746, Korea
}

\begin{abstract}
Direct cell-cell communication through connexin $(\mathrm{Cx})$ complexes is a way to achieve functional accordance of cells within a tissue or an organ. The initial segment (IS), a part of the epididymis, plays important roles in sperm maturation. Steroid hormones influence on expression of a number of genes in the IS of adult animals. However, developmental effect of sex hormones on the gene expression in the IS has not been examined. In this study, estradiol benzoate (EB, an estrogen agonist) or flutamide (Flu, an androgen antagonist) was exogenously administrated at 1 week of postnatal age, and expressional changes of $C x$ genes in the IS were determined at 4 months of age by a quantitative real-time PCR analysis. Treatment of EB at $0.015 \mu \mathrm{g} / \mathrm{kg}$ body weight (BW) increased expression of $C x 30.3,31.1$, and 43 genes. However, treatment of $1.5 \mu \mathrm{g} \mathrm{EB} / \mathrm{kg}$ BW resulted in expressional decreases of $C x 31,32$, and 45 genes and caused increases of $C x 30.3$ and 43 gene expression. Significant decreases of $C x 31,31.1,32,37$, and 45 gene expression were detected with a treatment of $500 \mu \mathrm{g}$ Flu/kg BW, while expression of $C x 43$ gene was significantly increased with a treatment of $500 \mu \mathrm{g} \mathrm{Flu} / \mathrm{kg}$ BW. A treatment of $50 \mathrm{mg} \mathrm{Flu} / \mathrm{kg} \mathrm{BW}$ led to significant increases of $C x 30.3,32,37,40$, and 43 gene expression. These findings imply that exogenous exposure of steroidal hormones during the early developmental period would result in aberrant expression of $C x$ genes in the adult IS.
\end{abstract}

Key words : Initial segment, Connexin, Estradiol benzoate, Flutamide, Gene expression

\section{INTRODUCTION}

Proper maturation of spermatozoa released from the testis is chiefly occurred in the epididymis and absolutely required for successful male reproduction. Depending on morphological and functional characteristics, the epididymis is divided into initial segment (IS), caput epididymis, corpus epididymis, and cauda epididymis (Cosentino \& Cockett, 1986). The epithelium of the IS is composed of several cell types, including principal, basal, and halo cells, which are frequently found throughout the entire epididymis (Robaire \&
Hermo, 1988). However, the epithelial layer also has narrow and apical cells that are exclusively present in the IS (Robaire \& Hermo, 1988). Several researches have demonstrated that the luminal composition of the IS is distinguishable from the other parts of the epididymis (reviews in Robaire \& Hermo, 1988). In addition, distinct epithelial localization of enzymatic molecules indicates that the function of the IS would be different from the rest of the epididymal region (Adamali \& Hermo, 1996). Together, these observations imply that functional regulation of the IS is likely controlled by a different manner from other epididymal

\footnotetext{
Manuscript received 4 December 2014, Received in revised form 10 December 2014, Accepted 11 December 2014

${ }^{\dagger}$ Corresponding Author : Ki-Ho Lee, Dept. of Biochemistry and Molecular Biology, College of Medicine, Eulji University, Daejeon 301-746, Korea. Tel. : +82-42-259-1643, Fax : +82-42-259-1649, E-mail : kiholee@eulji.ac.kr

This is an Open Access article distributed under the terms of the Creative Commons Attribution Non-Commercial License (http:// creativecommons.org/licenses/by-nc/3.0) which permits unrestricted non-commercial use, distribution, and reproduction in any medium, provided the original work is properly cited.
} 
parts.

Precisely regulated coordination among cells is absolutely required to maintain functions of a tissue. Specially, direct interaction between neighboring cells is important in the functional regulation of mammalian tissues, including the male reproductive organs (Pointies et al., 2005). There are three different types of direct cell-cell interactions, such as cadherin-based adhesion, occluding-based attachment, and connexin (Cx)-based gap junction (Pointies et al., 2005). Of these, only $\mathrm{Cx}$-based gap junction allows direct exchange of intracellular exchange of signal molecules between cytoplasm of adjacent cells (Goodenough et al., 1996). The gap junction is a complex of two homo- or heteromeric hemichannels, which each hemichannel is consisted of six Cxs (Cyr, 2011). More than $20 \mathrm{Cx}$ isoforms in mammals have been identified up to date (Meşe et al., 2007). Several researches have demonstrated the presence of Cxs in the male reproductive tract (Cry, 2011; Lee, 2013; Seo et al., 2010). Segment-specific expression of Cxs in the epididymis during postnatal development has been reported (Dufresne et al., 2003). Our previous study showed the expression of 8 Cxs, including Cx30.3, 31, 31.1, 32, 37, 40, 43, and 45, in the IS during postnatal period (Seo et al., 2010). Expressional levels of some Cxs are generally high at puberty and adulthood, while others have shown the highest expression at prepubertal age (Seo et al., 2010). Expression of $\mathrm{Cx} 32$ and 37 in the IS during postnatal period is fluctuated (Seo et al., 2010). These observations indicate the complexity of expressional regulation of $\mathrm{Cx}$ genes in the IS. Less attention has been paid on the regulation of $\mathrm{Cx}$ gene expression in the IS. St-Pierre et al. (2003) have shown that induction of hypothyroidism during neonatal period results in a decrease of $\mathrm{Cx} 43$ expression in the IS of adult rat, implying hormonal regulation of the expression of $\mathrm{Cx}$ genes in the IS. Another study demonstrates a possibility of expressional regulation of $\mathrm{Cx} 43$ by epidermal growth factor in human cauda epididymis (Dubé et al., 2012). However, more detailed examination has not been attempted to reveal expressional regulation of $\mathrm{Cx}$ genes in the IS.

It is well known that the epididymis is steroid hormoneresponsive tissue. There is no doubt that the function and structure of epididymis are chiefly under the regulation of androgens (Robaire \& Hamzeh, 2011). In addition, there are growing numbers of evidence of demonstrating the effect of estrogens on the regulation of epididymal functions (Joseph et al., 2011). Such effects of androgens and estrogens on the epididymis are exerted by modulating the expression of various genes associated with structural and functional regulation of the epididymis (Joseph et al., 2011; Robaire $\&$ Hamzeh, 2011). Yet, the effect of steroid hormones on expression of $\mathrm{Cx}$ genes in the IS has not been thoroughly studied. As mentioned earlier, our previous research shows the existence and differential expressional patterns of several $\mathrm{Cx}$ isoforms in the IS during postnatal development (Seo et al., 2010). Thus, in the present study, we attempted to show if neonatal treatment of flutamide, an anti-androgen, or estradiol benzoate, an estrogen agonist, gives an influence on the expression of $\mathrm{Cx}$ genes in the IS of adult rat.

\section{MATERIALS AND METHODS}

\section{Experimental animals and estradiol benzoate} (EB) and flutamide (Flu) treatment

Five pregnant female Spragure Dawley rats were purchased from Samtako (OSan, Korea) and individually caged upon the arrival. Food and drinking water were free access to food and drinking water for the entire experimental period. Each pregnant female rat was randomly assigned into one of five different experimental groups, control, low-dose EB-treated (EB-L), high-dose EB-treated (EB-H), low-dose Flu-treated (Flu-L), or high-dose Flu-treated (Flu-H) group. At the end of the term, 5 to 8 male pups were delivered from each female rat.

The powder of EB and Flu purchased from Tokyo 
Expressional Modulation of Connexin Isoforms in the Initial Segment of Male Rat treated with Estradiol Benzoate or Flutamide

Chemical Industry Co. (Tokyo, Japan) was completely dissolved in $100 \% \mathrm{EtOH}$ at room temperature, and then diluted in sesame oil. When the pups became 7 days of postnatal age, each pup was weighted and subcutaneously injected by EB at the final concentration of either 0.015 or $1.5 \mu \mathrm{g} / \mathrm{kg}$ body weight (BW) for EB-L or EB-H, respectively, or Flu at the final concentration of either $500 \mu \mathrm{g}$ or 50 $\mathrm{mg} / \mathrm{kg} \mathrm{BW}$ for Flu-L or Flu-H, respectively. Control animals were treated by sesame oil of same amount.

\section{Collection of tissue and isolation of total RNA}

Once sexually mature at 4 months of age, the animals were anesthetized by $\mathrm{CO}_{2}$ stunning and the reproductive tract was exposed through an incision on lower abdomen. The reproductive tract was placed in cold PBS, and the epididymis was carefully dissected out from the rest parts of the reproductive tract. The IS was separated from the epididymis and washed a couple of times in fresh cold PBS before freezing in liquid nitrogen. The IS was stored in $-80^{\circ} \mathrm{C}$ until used for total RNA isolation. In total, 31 male rats were used for the present research, including control $(n=5)$, EB-L (n=7), EB-H (n=7), Flu-L (n=6), and Flu-H (n=6).

To isolate total RNA from the tissues, frozen IS was first homogenized in easy-Blue total RNA extraction solution (iNtRON Biotech, Sungnam, S.Korea) with a polytron homogenizer (Fisher Scientific, Pittsburgh, PA). Then, using phenol-chloroform extraction method, a pellet of total RNA was collected and resuspended in DEPC-treated $\mathrm{dH}_{2} \mathrm{O}$. Qualitative evaluation of isolated total RNA was carried out with gel electrophoresis, and the amount of total RNA was acquired by quantitative analysis with an UV spectro-

Table 1. Oligonucleotide primers for real-time PCR analysis

\begin{tabular}{|c|c|c|c|}
\hline $\begin{array}{c}\text { Gene } \\
\text { (GenBank ID) }\end{array}$ & $\begin{array}{l}\text { Primer sequence } \\
\qquad\left(5^{\prime} \rightarrow 3^{\prime}\right)\end{array}$ & $\begin{array}{l}\mathrm{T}_{\mathrm{m}} \\
\left({ }^{\circ} \mathrm{C}\right)\end{array}$ & $\begin{array}{l}\text { PCR product } \\
\text { size (bps) }\end{array}$ \\
\hline $\begin{array}{c}C \times 30.3 \\
\left(\mathrm{NM} \_053984\right)\end{array}$ & $\begin{array}{l}\text { (F) CCCAATGTCTGCTATGACGA } \\
\text { (R) CACAGCAGCCTTGAAGATGA }\end{array}$ & 57 & 243 \\
\hline $\begin{array}{c}C \times 31 \\
\left(\mathrm{NM} \_019240\right)\end{array}$ & $\begin{array}{l}\text { (F) TTGAGCGGTGTGAACCAGTA } \\
\text { (R) TGTTGGAGATGGGGAAGAAG }\end{array}$ & 57 & 193 \\
\hline $\begin{array}{c}C x 31.1 \\
\left(\mathrm{NM} \_019241\right)\end{array}$ & $\begin{array}{l}\text { (F) CATCGTCTGCATCCTGCTTA } \\
\text { (R) ATGAGGTCGCTTGAGAGGAA }\end{array}$ & 55 & 165 \\
\hline $\begin{array}{c}C \times 32 \\
\left(\mathrm{NM} \_017251\right)\end{array}$ & $\begin{array}{l}\text { (F) AGAATCATGGTGCTGGTGGT } \\
\text { (R) CCTCAAGCCGTAGCATTTTC }\end{array}$ & 57 & 235 \\
\hline $\begin{array}{c}C x 37 \\
(\text { NM_021654) }\end{array}$ & $\begin{array}{l}\text { (F) AGTGTCTGTACCTTGGATGCC } \\
\text { (R) CAGCACACTTAGCCAAGAGC }\end{array}$ & 51 & 223 \\
\hline $\begin{array}{c}C x 40 \\
\left(\mathrm{NM} \_019280\right)\end{array}$ & $\begin{array}{l}\text { (F) ATACCATTCAGCCTGGTTGC } \\
\text { (R) CGGCCTCTTTAGCTTTCTCA }\end{array}$ & 57 & 189 \\
\hline $\begin{array}{c}C x 43 \\
\left(\mathrm{NM} \_012567\right)\end{array}$ & $\begin{array}{l}\text { (F) AGCAAGCTAGCGAGCAAAAC } \\
\text { (R) GAGTTCATGTCCAGCAGCAA }\end{array}$ & 55 & 151 \\
\hline $\begin{array}{c}C x 45 \\
\left(\mathrm{NM} \_001085381\right)\end{array}$ & $\begin{array}{l}\text { (F) GATCATCCTGGTTGCTACTC } \\
\text { (R) GATCCTCTTCATGGTCCTCT }\end{array}$ & 51 & 173 \\
\hline Ppia & $\begin{array}{l}\text { (F) GGCAAATGCTGGACCAAACAC } \\
\text { (R) TTAGAGTTGTCCACAGTCGGAGATG }\end{array}$ & 59 & 196 \\
\hline
\end{tabular}

$C x$ : connexin; Ppia : peptidylprolyl isomerase A (cyclophilin A). 
photometer (Eppendorf, New York, USA). The total RNAs were stored in $-80^{\circ} \mathrm{C}$ until utilized for cDNA generation.

\section{3. cDNA generation and quantitative real-time PCR} analysis

The first strand of cDNA was generated from $1 \mu \mathrm{g}$ of total RNA, using oligo-dT primer and ImProm-II ${ }^{\mathrm{TM}}$ reverse transcription system (Promega, Madison, USA). The reverse transcription $(\mathrm{RT})$ reaction was carried out at $25^{\circ} \mathrm{C}$ for 5 $\min , 42^{\circ} \mathrm{C}$ for $1 \mathrm{hr}$ and $30 \mathrm{~min}$, and $70^{\circ} \mathrm{C}$ for $15 \mathrm{~min}$. The cDNA was directly used for quantitative real-time PCR to determine expressional levels of connexin $(C x)$ isoforms in the IS of experimental animals. Table 1 presents information of oligonucleotide primers utilized for real-time PCR analysis in the present study.

The PCR cocktail was prepared with $1 \mu \mathrm{L}$ of cDNA, 10 pmol of primer set, $10 \mu \mathrm{L}$ of master mixture (Finnzymes, Espoo, Finland), and water to make a final volume of $20 \mu \mathrm{L}$. The PCR was carried out by cycles of denaturation at $95^{\circ} \mathrm{C}$ for 30 sec, annealing at $\mathrm{T}_{\mathrm{m}}$ for $30 \mathrm{sec}$, and extension at $72^{\circ} \mathrm{C}$ for $30 \mathrm{sec}$. At the end of each PCR, an additional extension step at $72^{\circ} \mathrm{C}$ for 10 min was included. Cyclophilin A (Ppia) was used as a PCR internal quantitative control. Expected sizes of PCR products were confirmed by $1.2 \%$ agarose gel electrophoresis.

\section{Statistical analysis and data presentation}

The RT reaction and PCR were independently quadruplicated to get a mean and a standard error for each experimental group. Experimental results are present in relative ratios of expression between Ppia and $C x$ isoform. Statistical comparisons of gene expression levels among experimental groups of each treatment were carried out by one-way ANOVA, followed by a post-hoc analysis, Duncan'test. When $P$ value was lower than 0.05 , the result was considered as statistically significant.

\section{RESULTS}

1. Expression of $C \times 30.3$ and $C \times 31$ genes in the initial segment of adult rat treated with estradiol benzoate or flutamide at 1 week of postnatal age

Expression of $C \times 30.3$ in the IS at the adult was significantly increased by EB treatment at 1 week of age, even though there was no difference on $C \times 30.3$ expressional level between low and high dose treatment of EB (Fig. 1a). A treatment of low-dose Flu caused no significant change in $C x 30.3$ mRNA level in the IS, even though a high-dose

a)

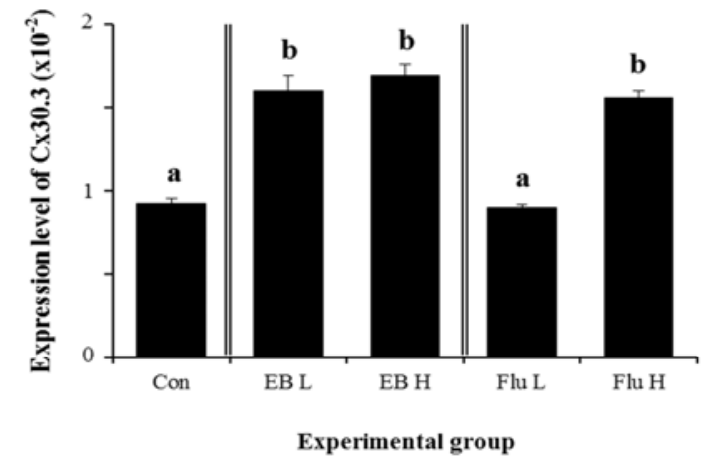

b)

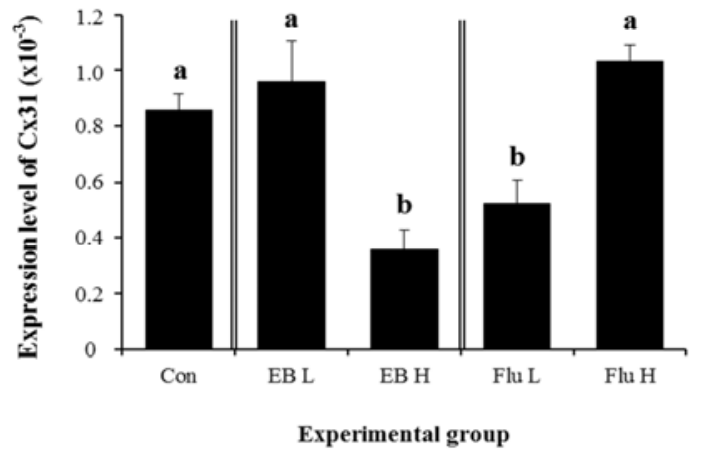

Fig. 1. Expression of $\mathrm{Cx} 30.3$ and $\mathrm{Cx31}$ genes in the initial segment of adult rat treated with estradiol benzoate or flutamide at 1 week of postnatal age. Animals were treated with either estradiol benzoate at low (EB L, $0.015 \mu \mathrm{g} / \mathrm{kg} \mathrm{BW}$ ) or high (EB H, $1.5 \mu \mathrm{g} / \mathrm{kg}$ $\mathrm{BW}$ ) or flutamide at low (Flu L, $500 \mu \mathrm{g} / \mathrm{kg} \mathrm{BW}$ ) or high (Flu H, $50 \mathrm{mg} / \mathrm{kg} \mathrm{BW}$ ) dose. Control animals were administrated with peanut oil. Different letters indicate statistically significant differences at $p<$ 0.05 level, compared with control. 
Flu treatment at 1 week of age resulted in a significant elevation of $C x 30.3$ expression in the adult IS (Fig. 1a). Expressional level of $C \times 31$ in the adult IS was not affected by low-dose EB treatment at 1 week of age (Fig. 1b). But, a treatment of high-dose EB led to a significant decrease of Cx31 transcript level (Fig. 1b). In contrast with $C \times 31$, a treatment of low-dose Flu caused a significant decrease of Cx31 expression, while there was no change on Cx31 mRNA level by high-dose Flu treatment (Fig. 1b).

2. Expression of $C \times 31.1$ and $C \times 32$ genes in the initial segment of adult rat treated with estradiol benzoate or flutamide at 1 week of postnatal age

A significant increase of Cx31.1 mRNA level in the adult IS was observed with a treatment of low-dose EB at 1 week of age (Fig. 2a). However, a treatment of high-dose EB didn't give an influence on gene expression of $C \times 31.1$ (Fig. 2a). Expression of $C \times 31.1$ gene in the adult IS was significantly decreased by low-dose Flu treatment at 1 week of age, while no significant change of $C \times 31.1$ transcript level was detected with a treatment of high-dose Flu (Fig. 2a). A treatment of high-dose EB resulted in a significant decrease of $C x 32$ transcript abundance, but expression of Cx32 gene was not changed with low-dose EB treatment (Fig. 2b). A significant drop of $C x 32$ mRNA level was detected in low-dose Flu-treated group (Fig. 2b). Compared with that of control, expressional level of Cx32 gene in Flu-treated group at a high dose was significantly increased (Fig. 2b)

3. Expression of $C \times 37$ and $C \times 40$ genes in the initial segment of adult rat treated with estradiol benzoate or flutamide at 1 week of postnatal age

There was no significant impact on gene expression of $C \times 37$ in the adult IS by treatments of EB at 1 week of age (Fig. 3a). A significant decrease of $C \times 37$ mRNA level was found in low-dose Flu-treated group (Fig. 3a). A treatment of high-dose Flu at 1 week of age resulted in a significant

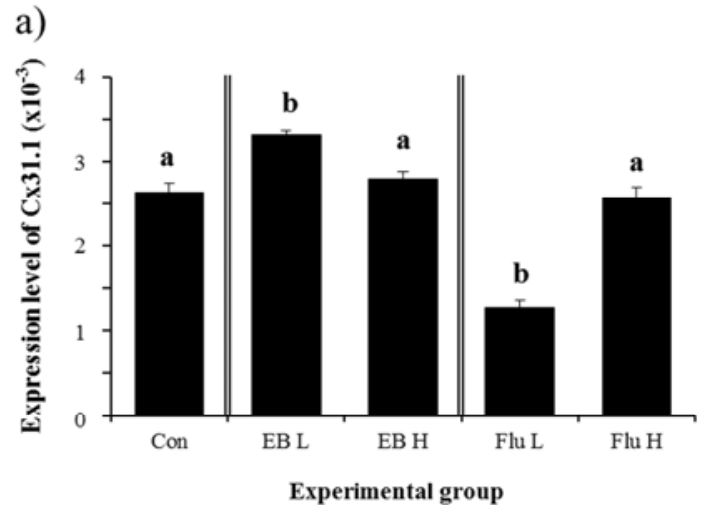

b)

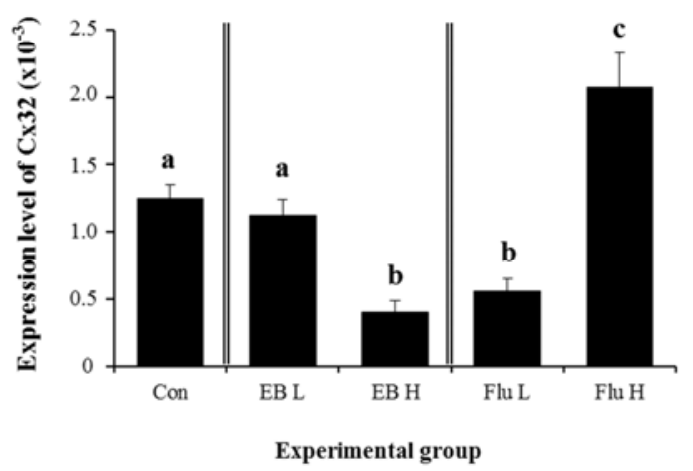

Fig. 2. Expression of $\mathrm{Cx31.1}$ and $\mathrm{Cx32}$ genes in the initial segment of adult rat treated with estradiol benzoate or flutamide at 1 week of postnatal age. Animals were treated with either estradiol benzoate at low (EB L, $0.015 \mu \mathrm{g} / \mathrm{kg} \mathrm{BW}$ ) or high (EB H, $1.5 \mu \mathrm{g} / \mathrm{kg}$ $\mathrm{BW}$ ) or flutamide at low (Flu L, $500 \mu \mathrm{g} / \mathrm{kg} \mathrm{BW}$ ) or high (Flu H, $50 \mathrm{mg} / \mathrm{kg} \mathrm{BW}$ ) dose. Control animals were administrated with peanut oil. Different letters indicate statistically significant differences at $p<$ 0.05 level, compared with control.

increase of $C \times 37$ expressional level, compared with that of control (Fig. 3a). Similarly, expression of $C x 40$ gene was not modulated by treatments of EB (Fig. 3b). No significant change of $C x 40$ gene was observed with a treatment of low-dose Flu (Fig. 3b). However, expression of $C x 40$ gene was significantly increased by a treatment of high-dose Flu (Fig. 3b).

4. Expression of $C x 43$ and $C x 45$ genes in the initial segment of adult rat treated with estradiol benzoate or flutamide at 1 week of postnatal age 
a)

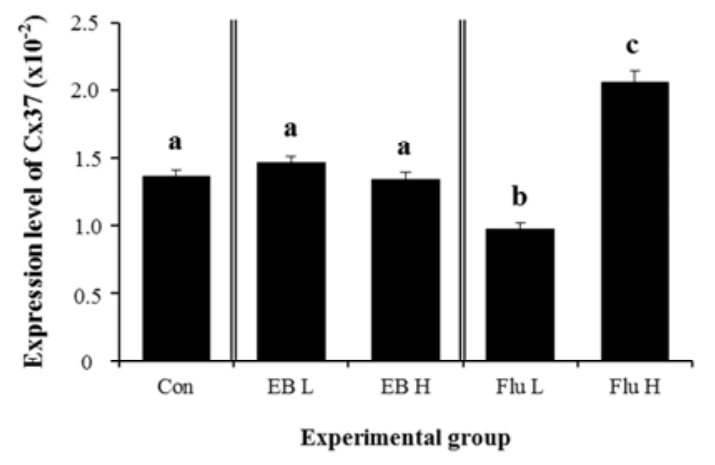

b)

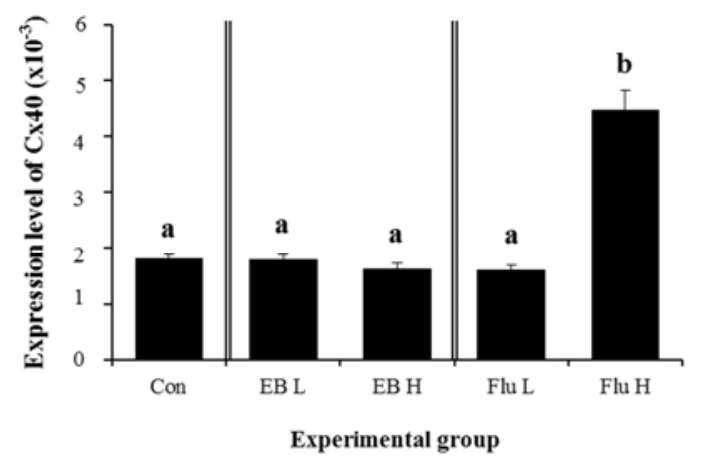

Fig. 3. Expression of $\mathrm{Cx} 37$ and $\mathrm{Cx} 40$ genes in the initial segment of adult rat treated with estradiol benzoate or flutamide at 1 week of postnatal age. Animals were treated with either estradiol benzoate at low (EB L, $0.015 \mu \mathrm{g} / \mathrm{kg} \mathrm{BW}$ ) or high (EB H, $1.5 \mu \mathrm{g} / \mathrm{kg}$ $\mathrm{BW}$ ) or flutamide at low (Flu L, $500 \mu \mathrm{g} / \mathrm{kg} \mathrm{BW}$ ) or high (Flu H, $50 \mathrm{mg} / \mathrm{kg} \mathrm{BW}$ ) dose. Control animals were administrated with peanut oil. Different letters indicate statistically significant differences at $p<$ 0.05 level, compared with control.

A significant increase of $C x 43$ mRNA level was detected in low-dose EB-treated group (Fig. 4a). Expression of $C x 43$ gene was further significantly increased by a treatment of high-dose EB (Fig. 4a). Similar expressional changes of $C x 43$ gene were observed with Flu treatment (Fig. 4a). Treatment of low-dose EB didn't result in a significant change of $C x 45$ gene expression, while a significant decrease of $C x 45$ mRNA level was induced by a treatment of high-dose EB (Fig. 4b). In the other hand, expression of $C x 45$ gene was significantly decreased by a treatment of a)

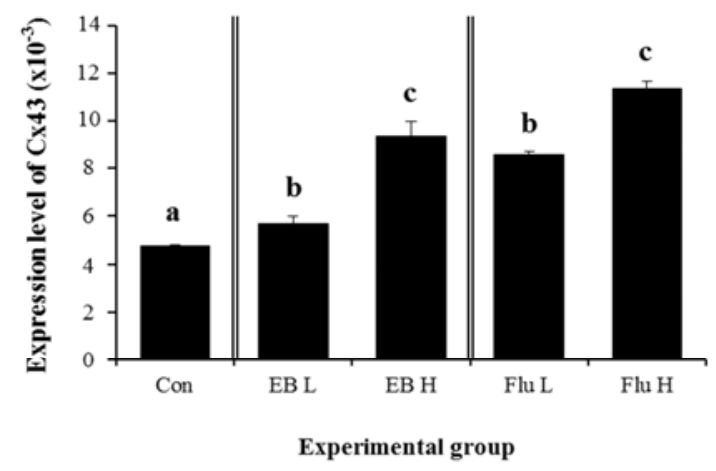

b)

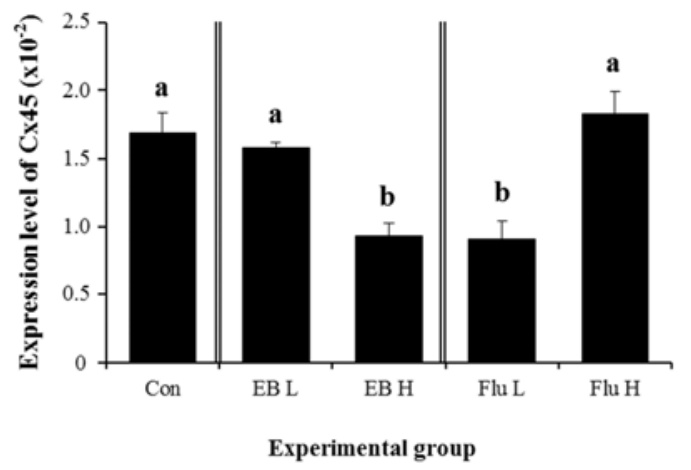

Fig. 4. Expression of $\mathrm{Cx} 43$ and $\mathrm{Cx} 45$ genes in the initial segment of adult rat treated with estradiol benzoate or flutamide at 1 week of postnatal age. Animals were treated with either estradiol benzoate at low (EB L, $0.015 \mu \mathrm{g} / \mathrm{kg} \mathrm{BW}$ ) or high (EB H, $1.5 \mu \mathrm{g} / \mathrm{kg}$ $\mathrm{BW}$ ) or flutamide at low (Flu L, $500 \mu \mathrm{g} / \mathrm{kg} \mathrm{BW}$ ) or high (Flu H, $50 \mathrm{mg} / \mathrm{kg} \mathrm{BW}$ ) dose. Control animals were administrated with peanut oil. Different letters indicate statistically significant differences at $p<$ 0.05 level, compared with control.

low-dose Flu, but was not affected by a treatment of highdose Flu (Fig. 4b).

\section{DISCUSSION}

Exposure to exogenous steroidal substances during the early postnatal development frequently results in disruption of systematic hormonal levels and consequently aberrant expression of genes associated with functional and structural maintenance of target tissues. The current study examined 
if administration of anti-androgenic or estrogenic substance at neonatal age would affect expression of $\mathrm{Cx}$ genes in the IS at the adult.

Neonatal exposure of bisphenol A (BPA), an environmental estrogenic compound, results in a decrease of $\mathrm{Cx} 43$ expression in the adult testis (Salian et al., 2009). In the present study, treatment of EB at low dose causes increases of Cx30.3, 31.1, and 43 gene expression, but not influences on the expression of other $\mathrm{Cx}$ genes. These findings suggest differential regulation of $\mathrm{Cx}$ gene expression by EB administration. Interestingly, expressional levels of $\mathrm{Cx}$ genes which were modulated by a treatment of EB at low dose are all increased but none is decreased. Such effects imply that a treatment of EB at low dose at neonatal age likely gives a permanent influence on $\mathrm{Cx}$ gene expression in the IS. At this point, it is not confirmed that expressional changes of these $\mathrm{Cx}$ genes are direct effects of $\mathrm{EB}$ action in the IS because the treatment of EB at neonatal age could give an impact on systematic balance of hormonal levels which would lead to secondary outcomes to regulate expression of $\mathrm{Cx}$ genes. Comparison of expressional levels of $\mathrm{Cx}$ gene in the IS at different recovery periods after neonatal EB exposure would provide helpful information to understand the effect of EB treatment at low dose on the expression of $\mathrm{Cx}$ genes.

The neonatal administration of EB at high dose results in expressional increases of Cx30.3 and 43 and expressional decreases of $\mathrm{Cx} 31,32$, and 45 in the adult IS. Treatment of EB at high dose does not affect the expressional change of Cx30.3 gene, indicating that $\mathrm{EB}$, regardless of the dose, stimulates transcription of Cx30.3 gene. Even though expression of $\mathrm{Cx} 31,32$, and 45 genes are not influenced by treatment of EB at low dose, EB treatment at high dose leads to considerable expressional decrease of these genes, suggesting suppression of transcription of these genes by a high-dose EB. There is no expressional change of $\mathrm{Cx} 37$ and 40 genes by EB treatment. No influence of EB on transcriptional regulation of $\mathrm{Cx} 37$ and 40 genes is inferred from these observations. Intriguingly, the treatment of EB at high dose results in a further increase of $\mathrm{Cx} 43$ gene expression but a decrease of Cx31.1 gene expression, compared with results by EB treatment at low dose. It seems that expression of $\mathrm{Cx} 31.1$ and 43 genes is regulated in an opposite manner by high-dose of EB in the IS. Additional researches are suggested to examine the effect of $\mathrm{EB}$ on transcriptional regulation of $\mathrm{Cx} 31.1$ and 43 genes.

Treatment of Flu at low dose at the neonatal age leads to decreases of transcriptional levels of most $\mathrm{Cx}$ genes, including $\mathrm{Cx} 31,31.1,32,37$, and 45. Interestingly, only significant increase of gene expression by a treatment of low-dose Flu is occurred in $\mathrm{Cx} 43$ gene, while expression of Cx30.3 and 40 genes is not affected by same treatment. Expressional pattern of $\mathrm{Cx} 31.1$ by EB treatment at low dose is opposite to that by Flu treatment at low dose, implying that transcription of Cx31.1 in the IS by steroid hormones seems more susceptible than the other $\mathrm{Cx}$ genes. Differential regulatory effects on gene expression in hypothalamus region treated with EB or Flu at neonatal period are demonstrated from Shibutani et al. (2007) study. Expressional changes of $\mathrm{Cx}$ gene by an administration of Flu at high dose differ with those by a treatment of Flue at low dose. Transcript levels of $\mathrm{Cx} 30.3,32,37,40$, and 43 are significantly increased, compared with those of control. Interestingly, expression of all $\mathrm{Cx}$ genes is remarkably increased, compared with those of Flu treatment at low dose, indicating a stimulatory effect of high-dose Flu treatment on expression of $\mathrm{Cx}$ genes. It is difficult to estimate how a treatment of Flu at high dose results in increases of $\mathrm{Cx}$ gene expression due to limited information available from the current study. Such effects of Flu on expression of $\mathrm{Cx}$ genes in the IS would be delivered from further examination with administration of various Flu doses.

Exposure to exogenous steroid hormones during neonatal period frequently results in alteration of gene expression at 
the adult. However, little information is available for expressional regulation of $\mathrm{Cx}$ genes in the IS. The present study demonstrates that EB or Flu treatment at neonatal age in male rat results in expressional modulation of most $\mathrm{Cx}$ genes in the adult IS. In addition, it is shown that expression of each $\mathrm{Cx}$ gene is differentially regulated by a type of steroid hormone and/or an amount of dose of the hormone. Moreover, the current research demonstrates a possibility of permanent and nonreversible effects induced by exposure to environmental steroid substances during the early postnatal period.

\section{ACKNOWLEDGEMENT}

This research was supported by Basic Science Research Program through the National Research Foundation of Korea (NRF) funded by the Ministry of Education, Science and Technology (20100022388).

\section{REFERENCES}

Adamali HI, Hermo L (1996) Apical and narrow cells are distinct cell types differing in their structure, distribution, and functions in the adult rat epididymis. J Androl $17: 208-222$.

Cosentino MJ, Cokett AT (1986) Structure and function of the epididymis. Urol Res 14:229-240.

Cyr DG (2011) Connexins and pannexins: coordinating cellular communication in the testis and epididymis. Spermatogenesis 1:325-338.

Dubé E, Dufresne J, Chan PT, Cyr DG (2012) Epidermal growth factor regulates connexin 43 in the human epididymis: role of gap junctions in azoospermia. Hum Reprod 27:2285-2296.

Dufresne J, Finnson KW, Gregory M, Cyr DG (2003) Expression of multiple connexins in the rat epididymis indicates a complex regulation of gap junctional communication. Am J Physiol Cell Physiol 284:33-43.
Goodenough DA, Goliger JA, Paul DL (1996) Connexins, connexons, and intercellular communication. Annu Rev Biochem 65:475-502.

Joseph A, Shur BD, Hess RA (2011) Estrogen, efferent ductules, and the epididymis. Biol Reprod 84:207-217.

Lee K-H (2013) Differential expression of multiple connexins in rat corpus and cauda epididymis at various postnatal stages. J Ani Sci Tech 55:521-530.

Meşe G, Richard G, White TW (2007) Gap junctions: basic structure and function. J Invest Dermatol 127:2516-2524.

Pointis G, Fiorini C, Defamie N, Segretain D (2005) Gap junctional communication in the male reproductive system. Biochim Biophy Acta 1719:102-116.

Robaire B, Hamzeh M (2011) Androgen action in the epididymis. J Androl 32:592-599.

Robaire B, Hermo L (1988) Efferent ducts, epididymis, and vas deferens: structure, functions, and their regulation. In: Knobil E et al (eds.). The Physiology of Reproduction. Raven Press, New York, NY, pp 999-1080.

Salian S, Doshi T, Vanage G (2009) Neonatal exposure of male rats to bisphenol A impairs fertility and expression of Sertoli cell junctional proteins in the testis. Toxicology 265:56-67.

Seo H-H, Seon C-W, Choi I, Cheon Y-P, Cheon T-H, Lee K-H (2010) Expressional profiling of connexin isoforms in the initial segment of the male reproductive tract during postnatal development. Reprod Dev Biol 34:103-109.

Shibutani M, Lee KY, Igarashi K, Woo GH, Inoue K, Nishimura T, Hirose M (2007) Hypothalamus regionspecific global gene expression profiling in early stages of central endocrine disruption in rat neonates injected with estradiol benzoate or flutamide. Dev Neurobiol 67:253-269.

St-Pierre N, Dufresne J, Rooney AA, Cyr DG (2003) Neonatal hypothyroidism alters the localization of gap junctional protein connexin 43 in the testis and messenger RNA levels in the epididymis of the rat. Biol Reprod 68:1232-1240. 